\title{
Building Consumer Loyalty through Servicescape in Shopping Malls
}

\author{
Shashikala R. ${ }^{1}$ and Dr. Suresh A. M. ${ }^{2}$ \\ ${ }^{1}$ Assistant Professor, MBA department, Dayananda Sagar College of Management and IT, Shavige Malleswara \\ Hills, Kumaraswamy Layout, Bangalore - 78 (Research Scholar in Bharathiar University, Coimbatore) \\ ${ }^{2}$ Professor and Director, NIAM Institute of Management, Bangalore (Research Supervisor in Bharathiar \\ University, Coimbatore)
}

\begin{abstract}
India is experiencing exponential growth in retail sector and Global Retail Development Index consecutively ranked as one of the most promising retail destinations of the world. Due to this reason lot of investments are happening in India and new players are entering the market. Shopping Mall being the latest organized retail format entering the market witnessed huge popularity and consumer attention, luring mall developers going all out to launch their projects. However the mushrooming growth of shopping malls has posed lot of challenges. Recent studies have revealed that $45 \%$ of the malls in cities are vacant. Poor mall management and poor tenant mix have resulted in poor mall traffic and low conversion rate. This paper attempts to explore the possibility of building consumer loyalty through effective use of servicescape (physical environment) in a shopping mall to attract and retain serious buyers. Study revealed that seven servicescape dimensions considered i.e., ambient factor, aesthetic factor, layout, variety, cleanliness, signs, symbols \& artifacts, and social factor are all relevant in shopping mall context and capable of inducing significant variations in consumer loyalty.
\end{abstract}

Key Words: behavioural intentions, consumer loyalty, environment, servicescape, shopping mall.

\section{Introduction}

India is witnessing the paradigm shift in the mall scenario, from just 3 malls in the year 2000 to 220 malls in the year 2006 to approximately 1,200 shopping malls at present. The number is expected to touch 1,500 by 2015 , as per the Assocham survey. Malls have transformed shopping from a need driven activity to a leisure time entertainment. Combining shopping, entertainment and eating-out in clean, air-conditioned comfort, malls are a refreshing change from the grind of shopping in overcrowded high streets. With the changing shopping needs and aspirations, consumers are finding it easier to shop at malls where a wide choice of merchandise is available under one roof. Malls have grown to become the ideal haunt for family outings, as these cater to the needs of adults and children alike.

However the mushrooming growth of shopping malls all over the major metros of India has posed lot of challenges. Recent studies have shown that not everything is bright and sunny as it seems and many retail players have jumped into the fray and joined the rat race without proper planning and strategy. A random survey by Assocham has revealed that $45 \%$ of the malls in cities are vacant. In fast-growing cities like Ahmedabad, Pune and the New Delhi region, vacancy rates at malls are more than 25 percent, according to property consultants Cushman \& Wakefield. Poor mall management and poor tenant mix have resulted in poor mall traffic and low conversion rate. Many shopping mall chains are witnessing disappointing traffic at their stores. This has led to the closure of individual shops, at several malls. Though in some cases the foot-falls have been great and phenomenal but not all footfalls are generating business. Not everyone who enters the mall is a prospective consumer, as majority of them come just to hang out, and indulge in window shopping in an airconditioned environment for free. Therefore the occupiers are finding it difficult to manage economically. With high real estate cost, many of these retailers have failed to break even, and business has been abysmally low, even non-existent at times. The challenges which many malls are facing today are to keep up with the competition, to attract retailers of a higher quality and to attract serious buyers. At this juncture mall developers need to think of the innovative ways to increase center's sales and profits. This paper attempts to explore the possibility of building consumer loyalty through effective use of servicescape (physical environment) in a shopping mall.

\section{Servicescape}

Services capes, word coined by Bitner broadly refers to the way service environments are designed and managed where service is performed, delivered and consumed [1]. Servicescape comprises of both tangible and intangible cues which are capable of influencing customer service experiences to a greater extent. As services 
are intangible in nature, often consumers look for physical cues (tangibles) while evaluating service options [2]. Servicescape which is rich in such physical cues therefore helps in both creating service expectations and assessing service perceptions. According to Bitner, servicescape has three major dimensions: Ambient factors (lighting, scent, air quality, temperature, music, and noise), Spatial layout and functionality (the existence and arrangement of machinery, equipments, and furnishings) and Signs, symbols, and artifacts (signage, artwork and decorative items, POP displays) [1]. The influence of servicescape is more obvious in services such as hotels, retail stores, hospitals, amusement parks, where customers spend extended periods of time in the physical surroundings of the service provider. Further servicescapes may influence employees and/or customers and/or their interactions. In case of interpersonal services such as retail outlets and restaurants servicescape may influence behaviors of both customers and employees, and also enhance the service experience by facilitating the interaction between them [2]. Recent empirical research has revealed that the very design of a store may translate in to more happier customers, longer stays, higher spending, and faster and efficient service, all of which may have considerable effect on organization's bottom line.

\section{Servicescape and Consumer Loyalty}

Many researchers have proved that servicescape can substantially influence consumer satisfactions and subsequent behaviours under varied service settings [3][4][5][6][7]. Donovan and Rossiter first introduced the Mehrabian-Russell (M-R) environmental psychology model into the store atmosphere literature which holds that the environment and its perception (conscious and unconscious) influences emotional responses: pleasure and arousal. These emotional responses in turn lead to approach/avoidance behaviors that include shopping enjoyment, friendliness toward others, desire to explore, desire to stay for long and unplanned spending [2]. The perceived quality of the servicescape may play an important role in determining whether or not consumers are satisfied, which in turn influences behavioural intentions [1]. Further servicescape (tangibles of SERVQUAL) may influence service quality both directly and indirectly by influencing the perception of intangible service quality dimensions [8]. Music, lights, colours, displays, fragrances, a soft and cosy ambience and many more elements shape shoppers' mood and behavior [9].

Servicescape has been consistently associated with customer loyalty or patronage intentions in retail settings. Environment was the major factor in predicting the consumer loyalty in shopping malls [10]. Andreu et al., showed that, positive perceptions of a retail environment positively influence emotions and repatronage intentions [11]. Simpeh, et al., (2011) found that all three Bitner's (1992) servicescape factors: ambience, spatial layout and signs, symbols and artifacts were positively associated with customer patronage. Tripathi and Siddiqui, found positive relationships among perceived servicescape, customer satisfaction and revisit intentions in shopping malls [12]. Further atmospheric cues are positively correlated with patronage intentions when consumers perceived more hedonic value than utilitarian value as in case of shopping malls [13]. Baker, Parasuraman, Grewal, \& Voss, found that store employee and store design perceptions positively affect the interpersonal service quality which in turn has a positive effect on store patronage intentions [14].

\section{Dimensions of Shopping Mall Servicescape}

Researchers have explored many dimensions of servicescape especially in shopping malls context which together affect the customer behavioural intentions.

1.1 Ambient Factor - Ambient factors include background variables such as lighting, aroma, noise, music, air quality and temperature which affect the non-visual senses. Though these variables are not part of the primary service but their absence may make customers feel uncomfortable.

1.1.1 Music - Atmospheric music (tempo, volume and preference) is known to have tremendous impact on consumer responses. Customers have specific preferences towards music and its evaluation can influence the overall satisfaction. Under slow music people tend to move slowly, explore more, stay for long and end up paying more in a supermarket [15]. Also customers selected more expensive merchandise when classical music was played in the background [16]. Moreover shopping time and expenditures were observed to increase with the level of preference for the background music [17].

1.1.2 Aroma - Pleasant ambient odor has significant effects on consumer perceived value [13] and the amount of time spent in the store [18]. Pleasant scents increased the amount of time a consumer spent in the store [19]. Also shoppers in the scented condition perceived that they had spent less time in the store than shoppers in the no-scent condition [20]. Further in-store aroma influences consumer emotions of pleasure and arousal [21]. 
1.1.3 Lighting - lighting makes a significant contribution on how a customer experiences a space [22]. Right lighting has been proven to influence the shopping behaviour of customers positively [23]. Brighter lighting influenced shoppers to examine and handle more products [16]. Further customers engaged in general communication in bright environments, whereas more intimate conversation occurred in softer light [24].

1.1.4 Temperature - The tactile factors such as temperature and air quality may help in creating a holistic atmosphere in a retail store. These cues signal store's merchandize quality, clientele, comfort, and have significant and positive impact on store image. Store temperature (air conditioning) potentially increases customers' value due to personal comfort and aesthetic values [13]. Moreover shopping malls that are too hot make the buyer dissatisfied [25].These factors increase customers' exploratory tendencies and sensation seeking behavior and can potentially alter emotional experiences.

Based on above discussion it can be assumed that:

$\mathrm{H}_{1}$ : There is a significant relationship between ambient factor and consumer loyalty.

1.2 Aesthetic Factor - Aesthetics refers to a function of architectural style, along with interior décor, colour scheme, pictures/paintings, plants/flowers, ceiling/wall decorations all of which customers can see and use to evaluate the aesthetic quality of the servicescape [6]. Aesthetic factors are important because they influence ambience. Other aesthetic factors include the surrounding external environment, the parking and visibility of the facility. Architectural design and interior décor of a shopping mall positively affects desire to stay [26] and higher levels of spending [27]. Store colour is said to influence the trust and store choice. Blue ambient color generates more trust in subjects than green ambient color which in turn significantly affects store choice [28]. Also consumers reacted more favorably to a blue environment in retail settings, where in "blue stores" had higher simulated purchase rates [29]. Colors also influenced emotional pleasure. Hence,

$\mathrm{H} 2$ : There is a significant relationship between aesthetic factor and consumer loyalty.

1.3 Layout - Spatial layout and functionality refers to the way in which machinery, equipment, and furnishings, seats, aisles, hallways and walkways, restrooms, and the entrance and exits are designed and arranged in service settings. These factors are important in many services (e.g., theaters, retail stores, concerts, upscale restaurants) because these can affect the comfort of the customer. Layout that makes people feel constricted may have a direct effect on customer quality perceptions, excitement levels, and indirectly on their desire to return [6]. Therefore we can assume that:

$\mathrm{H}_{3}$ : There is a significant relationship between layout and consumer loyalty.

1.4 Variety - Shopping mall that offers variety in tenant occupancy and product variety both in individual store and across competing stores is likely attracts more shoppers because of the excitement it generates. Tenant mix is said to influence mall selection, frequency of shopping and shopping centre image. Further mall variety measured on food service, stores and entertainment options has the strongest influence on customer excitement and desire to stay in the mall [26]. Variety of products has a significant influence on shoppers' satisfaction in shopping malls [30]. All these studies finally point out that:

$\mathrm{H}_{4}$ : There is a significant relationship between variety and consumer loyalty.

1.5 Sign, Symbols, and Artifacts - Signs, symbols, and artifacts include signage and décor used to communicate and enhance a certain image or mood, or to direct customers to desired destinations. It was found that signs, symbols and artifacts were positively associated with customer patronage [31]. Indeed, a service setting with legible (clear signage) arrangements may result in positive consumer moods, thus impacting on the relative spend during lunch [32]. These studies clearly state that:

$\mathrm{H}_{5}$ : There is a significant relationship between sign, symbols and artifacts and consumer loyalty.

1.6 Cleanliness - Cleanliness has been found to exert a strong influence on consumers' perceptions of retail stores and services. Cleanliness is important especially in those situations in which customers must spend several hours in the service setting and many consumers implicitly associate cleanliness with the quality of the servicescape. Cleanliness significantly affected the servicescape satisfaction of a slot floor in casino [33]. Further the cleanliness issues were most reported problems in servicescape failures in food service industry [34]. Hence it is assumed that:

$\mathrm{H}_{6}$ : There is a significant relationship between cleanliness and consumer loyalty.

1.7 Social Factor - Social elements are the employees and customers in the service setting [35]. These cues include physical appearance, number, gender and attire of employees and of other customers. Presence of more social cues in store environment may lead to higher levels of arousal [36]. Bitner found that environment 
featuring an employee in less than professional attire could influence a customer's attribution and satisfaction when a service failure occurred [1]. Further, more number of sales personnel with professional attire, and greeting customers at the entrance of the store made customers perceive higher service quality [37]. Additionally in an open service encounter sites (e.g., banks, restaurants) where consumers could observe service delivery to other consumers, the way services were delivered influenced not only the opinions of the consumers who received the service, but also the opinions of other consumers who observed service delivery [38]. All these studies essentially points that:

$\mathrm{H}_{7}$ : There is a significant relationship between social factor and consumer loyalty.

Figure 1: Shopping Mall Services cape and Customer Loyalty

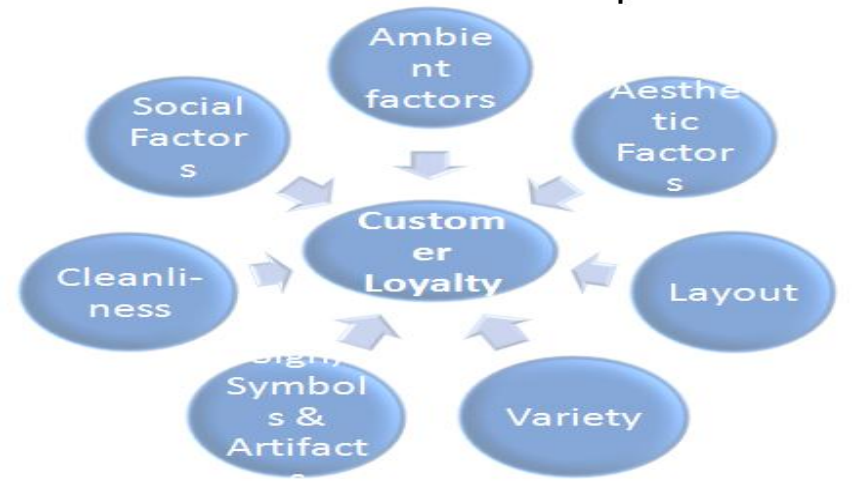

\section{Data Collection}

The data were collected through field survey by means of a self-administered questionnaire. All the constructs were measured using multi-item scales adopted from the previous studies on seven-point Likert-type scales (1- strongly disagree to 7 - strongly agree).The population for the study was defined as visitors of shopping malls in Bangalore. Total of 120 shoppers in selected shopping malls were interviewed inside the malls as they were experiencing the servicescape. The demographic profile of sample is given in Table 1.

Table 1: Sample Characteristics

\begin{tabular}{|l|l|l|l|l|l|}
\hline Characteristics & Frequency & Percent & $\begin{array}{l}\text { Valid } \\
\text { Percent }\end{array}$ & $\begin{array}{l}\text { Cumulativ } \\
\text { e Percent }\end{array}$ \\
\hline Gender & Male & 81 & 67.5 & 67.5 & 67.5 \\
& Female & 39 & 32.5 & 32.5 & 100.0 \\
\hline Age & $18-25 \mathrm{yrs}$ & 58 & 48.3 & 48.3 & 48.3 \\
& $26-35 \mathrm{yrs}$ & 29 & 24.2 & 24.2 & 72.5 \\
& $36-45 \mathrm{yrs}$ & 29 & 24.2 & 24.2 & 96.7 \\
& $46-55 \mathrm{yrs}$ & 4 & 3.3 & 3.3 & 100.0 \\
\hline Marital Status & Married & 64 & 53.3 & 53.3 & 53.3 \\
& Single & 56 & 46.7 & 46.7 & 100.0 \\
\hline Monthly Income & Below 20k & 55 & 45.8 & 45.8 & 45.8 \\
& $20-40 \mathrm{k}$ & 36 & 30.0 & 30.0 & 75.8 \\
& $40-60 \mathrm{k}$ & 27 & 22.5 & 22.5 & 98.3 \\
& Above 60k & 2 & 1.7 & 1.7 & 100.0 \\
\hline Occupational & Self-employed & 25 & 20.8 & 20.8 & 20.8 \\
& Employed & 42 & 35.0 & 35.0 & 55.8 \\
& Student & 51 & 42.5 & 42.5 & 98.3 \\
& Homemaker & 2 & 1.7 & 1.7 & 100.0 \\
\hline Shopping & Once a week & 47 & 39.2 & 39.2 & 39.2 \\
& Fortnightly & 31 & 25.8 & 25.8 & 65.0 \\
& Once a month & 15 & 12.5 & 12.5 & 77.5 \\
& Occasionally & 27 & 22.5 & 22.5 & 100.0 \\
\hline
\end{tabular}




\section{Data Analysis}

The data were analyzed using SPSS software 17.0 version. Reliability tests, Correlation and regression analysis were performed.

1.8 Reliability Statistics - To assess the internal consistency of the scale items, reliability statistics were computed for all the constructs and the same is presented in Table 2. Cronbach's Alpha coefficients are quiet high ranging from $0.678-0.909$ for all the constructs.

Table 2: Reliability Statistics

\begin{tabular}{|l|l|l|}
\hline Variables & Cronbach's Alpha & N of Items \\
\hline Ambient Factor & .823 & 8 \\
\hline Aesthetic Factor & .854 & 9 \\
\hline Layout & .783 & 7 \\
\hline Variety & .732 & 4 \\
\hline Cleanliness & .791 & 5 \\
\hline Signs, Symbols and Artifacts & .811 & 6 \\
\hline Social Factors & .909 & 15 \\
\hline Customer Loyalty & .678 & 3 \\
\hline
\end{tabular}

1.9 Correlation analysis - Correlation analysis was carried out to find out the direction and strength of the relationship between dependent and independent variables. Results of the same are presented in Table 3 . The Pearson correlation coefficients ( $\mathrm{p}$ value) range from 0.508 to 0.638 for all servicescape dimensions except for social factors which is 0.342 . However all correlations were significant at the 0.01 level for a 2 -tailed test. This indicates significant relationship between all the servicescape dimensions and customer loyalty. This proves the study hypotheses.

Table 3: Summary of Correlation Coefficients

\begin{tabular}{|c|c|c|c|c|c|c|c|}
\hline & $\begin{array}{l}\text { Ambient } \\
\text { Factor }\end{array}$ & $\begin{array}{l}\text { Aesthetic } \\
\text { Factor }\end{array}$ & Layout & Variety & Cleanliness & $\begin{array}{l}\text { Signs, Symbols } \\
\text { \& Artifacts }\end{array}$ & $\begin{array}{l}\text { Social } \\
\text { Factor }\end{array}$ \\
\hline $\begin{array}{l}\text { Customer } \\
\text { Loyalty }\end{array}$ & $\begin{array}{l}. \mathbf{6 3 8}^{* *} \\
.000\end{array}$ & $\begin{array}{l}.627^{* *} \\
.000\end{array}$ & $\begin{array}{l}.572^{* *} \\
.000\end{array}$ & $\begin{array}{l}.615^{* *} \\
.000\end{array}$ & $\begin{array}{l}. \mathbf{5 0 8}{ }^{* *} \\
.000\end{array}$ & $\begin{array}{l}.570^{* *} \\
.000\end{array}$ & $\begin{array}{l}. \mathbf{3 4 2} 2^{* *} \\
.000\end{array}$ \\
\hline
\end{tabular}

1.10 Regression Analysis - Regression analysis was performed to test for the predictive power of the dimensions of servicescape on customer loyalty. Table 4 represents the regression summary of the variables in the study. The table is indicating the value of $R=0.716$ ( $R$ ranges from -1 to 1 ) which shows the positive and strong relationship between the predictor variables and dependent variable. Regression coefficient is significant at the 0.05 level $\left(\mathrm{p}=0.000, \mathrm{R}^{2}=0.512\right.$ and $\left.\mathrm{F}=16.813\right)$. This substantiates the predictive power of servicescape dimensions on consumer loyalty. Further value of $R^{2}=0.512$ (greater than 0.5 ) illustrate that model is a good fit for data and is explaining the variation in dependent variable.

Table 4: Regression Summary

\begin{tabular}{|l|l|l|l|l|l|l|}
\hline Model & $\mathbf{R}$ & R Square & $\begin{array}{l}\text { Adjusted R } \\
\text { Square }\end{array}$ & $\begin{array}{l}\text { Std. Error of the } \\
\text { Estimate }\end{array}$ & F & Sig. \\
\hline 1 & $.716^{\mathrm{a}}$ & .512 & .482 & .55378 & 16.813 & $.000^{\mathrm{b}}$ \\
\hline
\end{tabular}

\section{Discussions}

First, the higher value of Chronbach's alpha shows that the multi-item scales used for measuring servicescape dimensions and customer loyalty are reliable. Though these scales have been developed in Western countries, their suitability for servicescape measurements in India is established. Also the items used for each construct will give the precise and accurate results in shopping malls context.

Second, the correlation results show positive relationship among the dependent and independent variables. The Pearson correlation (p) value for ambient factor and consumer loyalty is 0.638 and the significance value is 0.000 . P-value greater than 0.5 at significance level of 0.05 shows the strong and positive relationship among these variables. Therefore ambience which includes background music, scent, lighting, and temperature and air 
quality of a shopping mall is significantly associated with consumer loyalty. This study establishes the fact that if ambience of mall is enhanced consumers become more loyal.

P-value between aesthetic factor and loyalty is 0.627 with significance value of 0.000 , which shows a strong and positive relationship between aesthetics which comprised of architectural style, décor, colours, surrounding area, accessibility and visibility of a mall and consumer loyalty. Mall developers therefore need to invest in improving the aesthetic value of malls if they want their customers to visit again.

P-value of 0.615 and significance value of 0.000 between variety and loyalty denotes a strong and positive relationship among these variables. Hence, shopping malls providing high on variety in terms of stores, goods, food, and entertainment may be able to retain maximum number of consumers.

P-value of 0.572 between layout and loyalty suggests strong and positive relationship at significance value of 0.000 . Spatial layout which makes consumers get where they want to go easily with wider walking spaces and working lifts will definitely enhance consumer loyalty intentions towards that mall. In a country where the retail space is limited and sky rocketing real estate costs, mall developers need to work more creatively in this regard.

Further p-value between signs, symbols \& artifacts and loyalty is 0.570 , which is greater than 0.5 at significance level of 0.05 shows the strong and positive relationship among these variables. Sufficient, clear and easy to understand signage, attractive decorations and POP displays therefore greatly influence the consumer loyalty towards that mall.

Cleanliness with p-value of 0.508 and significance value of 0.000 is strongly associated with loyalty. Cleanliness measured on clean walkways, restrooms, food service areas, and parking area, hence is more influential in building consumer loyalty of a shopping mall.

Social factor with p-value of 0.342 , though less than 0.5 at $95 \%$ confidence level is also significantly related to consumer loyalty. Social factor includes physical appearance, friendliness and crowding of employees and other shoppers. This study proves that to some extent social factor do influence consumer loyalty in a shopping mall.

Finally, regression results with value of $\mathrm{R}=0.716$ show the positive and strong relationships between the predictor variables and dependent variable. Here ambience, aesthetics, layout, variety, signs, symbols \& artifacts, cleanliness, and social factors acting as the predictor variables induce a strong effect on consumer loyalty in a shopping mall. Therefore it can be concluded that malls featuring these aspects can build strong consumer loyalty and can have edge over other malls.

\section{Conclusions}

Study proves that servicescape plays a major role in building consumer loyalty in a shopping mall, which was the basic objective. Seven dimensions considered here i.e., ambient factor, aesthetic factor, layout, variety, cleanliness, signs, symbols \& artifacts, and social factor could able to induce significant variations in consumer loyalty. Therefore retail managers must design the servicecsape incorporating these aspects. Further periodic tracking of consumer perception on these elements and bringing in more favourable changes as and when required is essential. However studies with larger samples and on other retail formats are necessary in Indian context. Also future studies may analyse the relative importance of different servicescape elements in enhancing consumer loyalty, so that resources may be allocated accordingly. Finally the increasing competition among shopping malls encourages managers to take account of consumer experience in the shopping environment as a potential tool of differentiation and appropriate use of servicescape in overall retail strategy will definitely help them in not only attracting consumers but also retain them by providing excellent shopping experiences.

\section{References}

[1]. Bitner, (1992), "Servicescapes: The Impact of Physical Surroundings on Customers and Employees", Journal of Marketing, Vol. 56, 57-71

[2]. Parasuraman, Zeithaml and Berry, (1985), "A Conceptual Model of Service Quality and its Implications for Future Research", Journal of Marketing, pp. 35-48.

[3]. Mehrabian and Russell, (1974), “An Approach to Environmental Psychology", Cambridge, MA: Massachusetts Institute of Technology.

[4]. Donovan, and Rossiter, (1982). "Store Atmosphere: An Environmental Psychology Approach," Journal of Retailing, $58,34-57$.

[5]. Turley, L.W. and R. E. Milliman, (2000), "Atmospheric Effects on Shopping Behavior: A Review of the Experimental Literature", Journal of Business Research, 49, 193-211.

[6]. Wakefield \& Blodgett, (1996), "The effect of the servicescape on customers' behavioral intentions in leisure service settings", The Journal of Services Marketing, Vol. 10, No. 6, pp. 45-61.

[7]. Lin, (2004), "Evaluating a servicescape: the effect of cognition and emotion", Hospitality Management, 23, 163-178

[8]. Reimer, A. and R. Kuehn,(2005) "The impact of servicescape on quality perception", European Journal of Marketing, 39(7/8), 785808 .

[9]. Jain and Bagdare (2011). "Music and consumption experience: A review". Retail and Distribution Management, 39 : 289-302 
[10]. Fatima and Rasheed (2012), "Determining the Factors affecting Consumer Loyalty towards Shopping Malls", Global Advanced Research Journal of Management and Business Studies, Vol. 1(4), pp. 134-140. http://garj.org/garjmbs/index.htm

[11]. Andreu, Bigne, Chumpitaz and Swaen, (2006), "How Does the Perceived Retail Environment Influence Consumers' Emotional Experience? Evidence from Two Retail Settings", International Review of Retail, Distribution and Consumer Research, Vol. 16, No. $5,559-578$.

[12]. Tripathi, S N, and. Siddiqui M H, (2007), “The Impact of Servicescape on Quality Perception and Repatronage Intentions of Customers - With Specific Reference to Shopping Malls", AJMR, Volume 1, Issue 4/4.

[13]. Kumar, Garg, and Rahman (2010), "Influence of Retail Atmospherics on Customer Value in an Emerging Market Condition", Great Lakes Herald, Vol. 4, No. 1.

[14]. Baker, Parasuraman, Grewal, \& Voss, (2002), “The Influence of Multiple Store Environment Cues on Perceived Merchandise Value and Patronage Intentions”, Journal of Marketing, Vol. 66, 120-141.

[15]. Milliman, (1982), "Using Background Music to Affect the Behavior of Supermarket Shoppers", Journal of Marketing, Vol. 46, 8691.

[16]. Areni and Kim, (1993), "The Influence of Background Music on Shopping Behavior: Classical Versus Top-Forty Music in a Wine Store", Advances in Consumer Research, Volume 20.

[17]. Herrington, J D , (1996), "Effects of music in service environments: a field study", The Journal of Services Marketing, Vol. 10, Iss. 2; pg. 26.

[18]. Mitchell, Kahn \& Knasko, (1995), "There's something in the Air: Effects of Congruent and Incongruent Ambient Odor on Consumer Decision Making”, Journal of Consumer Research, Volume 22, pp. 229 -238.

[19]. Vaccaro, Yucetepe, T-Baumgarten, Lee, (2009), "The Impact of Atmospheric Scent and Music-Retail Consistency on Consumers in a Retail or Service Environment", Journal of International Business and Economics, Volume 9, Number 4.

[20]. Spangenberg, Crowley \& Henderson, (1996), "Improving the Store Environment: Do Olfactory Cues Affect Evaluations and Behaviors?, The Journal of Marketing, Vol. 60, No. 2, pp. 67-80.

[21]. Walsh, Hassan, Michaelidou, \& Beatty, (2009), "The mediating role of emotions in the link between store-environment cues, storechoice criteria and marketing outcomes”, Paper presented at AMA (American Marketing Association) Conference, Chicago, USA, $7 / 08 / 09-10 / 08 / 09$.

[22]. Ciani, "A study of how lighting can affect a guest's dining experience" (2010). Graduate Theses and Dissertations. Paper 11369. http://lib.dr.iastate.edu/etd/11369.

[23]. Levy, Weitz (2004). Retailing Management. The McGrow-Hill Companies.

[24]. Gifford R (1988), "Light, decor, Arousal, Comfort, and Communication", Journal of Environmental Psychology, Vol. 8, pp. 177-189.

[25]. d'Astous, A. (2000). "Irritating aspects of te shopping environment", Journal of Business Research, Vol.42, No.2, pp.149-56

[26]. Wakefield and Baker, (1998), "Excitement at the Mall: Determinants and Effects on Shopping Response", Journal of Retailing, Vol. 74, No. 4, pp. 515-539.

[27]. Garvin, (2009), "Experiential retailing: extraordinary store environments and purchase behavior", Masters Theses and Doctoral Dissertations, Paper 226. http://commons.emich.edu/theses/226

[28]. Lee \& Rao (2010), "Color and Store Choice in Electronic Commerce: The Explanatory Role Of Trust", Journal of Electronic Commerce Research, VOL.11, NO 2, pp. 110-126.

[29]. Bellizzi, J.A. and Hite, R.E. (1992). "Environmental color, consumer feelings and purchase likelihood," Psychology and Marketing, Vol.9, No.5, pp.347-63

[30]. Ahmed ZU, Ghingold M, Dahari Z (2007). Malasian Shopping Mall Behavior: An Exploratory Study. Asia Pacific Journal of. Marketing Logistics. 19(4): 331-348.

[31]. Simpeh K N, Simpeh M, Nasiru, Tawiah, (2011), "Servicescape and Customer Patronage of Three Star Hotels in Ghana's Metropolitan City of Accra, European Journal of Business and Management, Vol. 3, No.4.

[32]. Newman, (2007), "Uncovering Dimensionality in the Servicescape: Towards Legibility", Service Industries Journal, Vol. 27, Issue 1, p15-28.

[33]. Lucas, (2003), “The Determinants and Effects of Slot Servicescape Satisfaction in a Las Vegas Hotel Casino", UNLV Gaming Research and Review Journal, Vol. 7, Issue 1.

[34]. Hoffman, K.D. et.al. (2003). "A CIT investigation of servicescape failures and associated recovery strategies". Journal of Service Marketing, Vol. 17, No. 4, pp. 322-340.

[35]. Baker, J. (1987). "The role of the environment in marketing services : the consumer perspective", in Czepiel, J., Congram, C.A. and Shanahan, J (Eds), The Services Challenge : Integrateing for competitive Advantage, (American Marketing Association, Chicago, IL), pp.79-84

[36]. Baker, Grewal, and Levy. (1992). "An Experimental Approach to Making Retail Store Environmental Decisions," Journal of Retailing, 68 (Winter): 445-460.

[37]. Baker, J., Grewal, D. and Parasuraman, A. (1994), "The influence of store environment on quality inferences and store image", Journal of the Academy of Marketing Science, Vol. 22 No. 4, pp. 328-39.

[38]. Dube, Chebat, \& Morin, S. (1995), "The effects of background music on consumers' desire to affiliate in buyer-seller interactions", Psychology and Marketing, vol. 12, no. 4, pp.305-319 